Zendle, David ORCID:

https://orcid.org/0000-0003-0279-6439 and Bowden-Jones, Henrietta (2019) Is excessive use of social media an addiction? BMJ.

Downloaded from: http://ray.yorksj.ac.uk/id/eprint/3890/

The version presented here may differ from the published version or version of record. If you intend to cite from the work you are advised to consult the publisher's version: http://dx.doi.org/10.1136/bmj.12171

Research at York St John (RaY) is an institutional repository. It supports the principles of open access by making the research outputs of the University available in digital form. Copyright of the items stored in RaY reside with the authors and/or other copyright owners. Users may access full text items free of charge, and may download a copy for private study or non-commercial research. For further reuse terms, see licence terms governing individual outputs. Institutional Repository Policy Statement

\title{
RaY
}

Research at the University of York St John

For more information please contact RaY at ray@yorksj.ac.uk 


\title{
Is excessive use of social media an addiction?
}

\author{
We don't yet know, and social media companies must help us find out
}

\author{
David Zendle lecturer ${ }^{1}$, Henrietta Bowden-Jones psychiatrist and honorary lecturer ${ }^{2}$
}

${ }^{1}$ York St John University, UK; ${ }^{2}$ Imperial College London, UK

\begin{abstract}
Huge numbers of people use social media, such as Instagram, Facebook, and Snapchat. Some $77 \%$ of internet users in the UK have a social media profile, ${ }^{1}$ and one recent study estimates that $20 \%$ of adolescents may use social media for at least five hours every day. ${ }^{2}$ These levels of exposure to social media have led to considerable concern over whether its excessive use should be considered a distinct form of behavioural addiction, and clinically treated as such. ${ }^{3}$

Some of the available evidence supports this position. Excessive social media use has been linked to symptoms typically associated with substance use disorders and behavioural addictions. For example, it has been shown to coincide with higher levels of social anxiety ${ }^{4}$ and depressive symptoms. ${ }^{5-7}$ Furthermore, when describing interactions with social media, people commonly report experiences that mirror widely used criteria for establishing addiction ${ }^{8}$ - for example, the inability to reduce their use of social media despite wanting to, or the experience of withdrawal symptoms when they are unable to access social media. ${ }^{5}$
\end{abstract}

\section{Proceed with caution}

Social media addiction is not currently recognised in either the Diagnostic and Statistical Manual of Mental Disorders, fifth edition, (DSM-V) or the International Classification of Diseases, 11 th edition. Given the evidence outlined above, it may seem reasonable to support the pathologising of excessive social media use in a similar fashion to excessive gambling or alcohol use. We believe, however, that caution is warranted before defining "social media addiction" as a disorder. The inclusion of gambling disorder in the DSM-V was prompted by substantial evidence of parallels between disordered gambling behaviours and substance addictions. ${ }^{910}$ A similarly clear cut body of evidence does not yet exist for disordered social media use.

The literature on social media addiction overwhelmingly relies on self reported measures of both addiction and usage, rather than clinical diagnoses of the former and direct behavioural measures of the latter. For example, the Bergen Facebook addiction scale assesses the presence of withdrawal symptoms by asking participants questions such as: "How often during the past year have you become irritable if you have been prohibited from using Facebook?" prevalence of excessive social media use, this may be problematic. Little consensus exists regarding either how social media addiction should be measured or what actually are the specific cut-off points on a questionnaire to consider a person addicted. ${ }^{12}$ Indeed, analysis of the diagnostic accuracy of a prominent internet addiction questionnaire estimated that it may report false positives as often as $91 \%$ of the time. ${ }^{13}$

Complicating things further are the lack of high quality longitudinal studies in the social media addiction literature. This contrasts with research into disordered gambling, which commonly employs longitudinal designs. This has allowed researchers to understand the causes, effects, and progression of problem gambling, ${ }^{14-17}$ and draw specific parallels between gambling and other addictions, such as substance use disorders. ${ }^{18}$ Without this information, it is hard to understand whether excessive social media use mirrors other addictions in both its aetiology and its response to treatment.

\section{Known unknowns}

Understanding the course of compulsive social media use will be helpful to clinicians working in mental health. We don't know as yet whether intense social media use can lead to psychological distress and even psychiatric illness—-such as depression and anxiety-or whether people who are more likely to find the use of social media compulsive are the ones with predisposing traits towards these presentations and the accompanying low self esteem and insecurities we may see clinically.

The duration of compulsive behaviours on these platforms and the extent of the subsequent harm experienced in relation to academic, social, and work related pursuits is also unclear.

How do we tackle all these uncertainties? To begin with, funding organisations such as the Economic and Social Research Council and the Medical Research Council need to recognise the importance of funding large scale, preregistered longitudinal studies on the effects of social media. Similarly, treatment based on small scale research should be made available to assess the need in the community for this type of intervention, the types of activities that are proving compulsive, and the most effective treatment interventions. 
In the long run, using industry data will be the most effective way to understand how problematic the excessive use of social media is. The companies who profit from social media hold vast repositories of behavioural data regarding the interactions of their users. Facebook alone, for example, holds hundreds of petabytes of such information. ${ }^{19}$ While social media companies profit to the tune of billions of dollars per year from these datasets, ${ }^{20}$ researchers are forced to rely on small samples of error prone self reported data to work out what the effects of this commerce might be on society. Schemes like the Social Data Science Accelerator ${ }^{21}$ allow social media companies to share their data with researchers. It is of vital importance that governments and policymakers encourage these companies to do so.

Competing interests: We have read and understood BMJ policy on declaration of interests and declare the following: HB-J: I am the Royal College of Psychiatrists' spokesperson on behavioural addictions, DZ: none declared.

Provenance: Commissioned, not externally peer reviewed.

1 Ofcom. Adults' media use and attitudes report. 2018. www.ofcom.org.uk/_data/assets/ pdf file/0011/113222/Adults-Media-Use-and-Attitudes-Report-2018.pdf.

2 Scott H, Biello SM, Woods H. Social media use and adolescent sleep outcomes: cross-sectional findings from the UK Millennium Cohort Study. PsyArXiv Preprints 2019. https://osf.io/z7kpf.

3 Kuss DJ, Griffiths MD. Social networking sites and addiction: ten lessons learned. Int J Environ Res Public Health 2017;14:311. 10.3390/ijerph14030311 28304359

4 Lee-Won RJ, Herzog L, Park SG. Hooked on Facebook: the role of social anxiety and need for social assurance in problematic use of Facebook. Cyberpsychol Behav Soc Netw 2015;18:567-74. 10.1089/cyber.2015.0002 26383178

5 Bányai F, Zsila Á, Király O, et al. Problematic social media use: results from a large-scale nationally representative adolescent sample. PLoS One 2017;12:e0169839. 10.1371/journal.pone.016983928068404

6 Van Rooij AJ, Ferguson CJ, Van de Mheen D, Schoenmakers TM. Time to abandon internet addiction? Predicting problematic internet, game, and social media use from psychosocial well-being and application use. Clin Neuropsychiatry 2017;14:113-21.
7 Pontes HM. Investigating the differential effects of social networking site addiction and Internet gaming disorder on psychological health. J Behav Addict 2017;6:601-10. 10.1556/2006.6.2017.075 29130329

8 Griffiths MD, Kuss DJ, Demetrovics Z. Social networking addiction: an overview of preliminary findings. In: Rosenberg KP, Feder LC, eds. Behavioral Addictions. Academic Press, 2014: 119-41, http://www.sciencedirect.com/science/article/pii/ B978012407724900006910.1016/B978-0-12-407724-9.00006-9.

9 Potenza MN. Review. The neurobiology of pathological gambling and drug addiction: an overview and new findings. Philos Trans R Soc Lond B Biol Sci 2008;363:3181-9. 10.1098/rstb.2008.0100 18640909

10 American Psychiatric Association. Diagnostic and Statistical Manual of Mental Disorders. American Psychiatric Association, 2013.

11 Andreassen CS, Torsheim T, Brunborg GS, Pallesen S. Development of a Facebook addiction scale. Psychol Rep 2012;110:501-17. a.

2 Andreassen CS. Online social network site addiction: a comprehensive review. Curr Addict Rep 2015;2:175-8410.1007/s40429-015-0056-9.

13 Maráz A, Király O, Demetrovics Z. The diagnostic pitfalls of surveys: if you score positive on a test of addiction, you still have a good chance not to be addicted. A response to Billieux et al. J Behav Addict 2015. https://core.ac.uk/download/pdt/42938511.pdf.

14 Dowling NA, Merkouris SS, Greenwood CJ, Oldenhof E, Toumbourou JW, Youssef GJ. Early risk and protective factors for problem gambling: A systematic review and meta-analysis of longitudinal studies. Clin Psychol Rev 2017;51:109-24. 10.1016/j.cpr.2016.10.008 27855334

15 Jacques C, Ladouceur R, Ferland F. Impact of availability on gambling: a longitudinal study. Can J Psychiatry 2000;45:810-5. 10.1177/070674370004500904 11143830

16 LaPlante DA, Nelson SE, LaBrie RA, Shaffer HJ. Stability and progression of disordered gambling: lessons from longitudinal studies. Can J Psychiatry 2008;53:52-60. 10.1177/070674370805300108 18286872

17 Parhami I, Mojtabai R, Rosenthal RJ, Afifi TO, Fong TW. Gambling and the onset of comorbid mental disorders: a longitudinal study evaluating severity and specific symptoms. J Psychiatr Pract 2014;20:207-19. 10.1097/01.pra.0000450320.98988.7c 24847994

18 Leeman RF, Potenza MN. Similarities and differences between pathological gambling and substance use disorders: a focus on impulsivity and compulsivity. Psychopharmacology (Berl) 2012;219:469-90. 10.1007/s00213-011-2550-7 22057662

19 Wiener J, Bronson N. Facebook's top open data problems. Facebook Res 2014. https:// research.fb.com/facebook-s-top-open-data-problems.

20 Nieva R. Facebook still cashing in on user data as sales surge. CNET 2018, www.cnet. com/news/facebook-first-quarter-earnings-2018.

21 Przybylski A. Written evidence presented to the Commons Science and Technology Committee. 2018. http://data.parliament.uk/writtenevidence/committeeevidence.svc/ evidencedocument/science-and-technology-committee/impact-of-social-media-andscreenuse-on-young-peoples-health/written/83316.html.

Published by the BMJ Publishing Group Limited. For permission to use (where not already granted under a licence) please go to http://group.bmj.com/group/rights-licensing/ permissions 